\title{
PREDATION ON THE WESTERN HONEY BEE, APIS MELLIFERA L., BY THE HORNET, VESPA TROPICA (L.)
}

\section{By Michael Burget ${ }^{1}$ and Pongthep Akratanakul ${ }^{2}$}

Hornets of the genus Vespa are recognized as efficient and devastating predators of honey bees, especially in tropical and subtropical biomes. Of the four species of honey bees in the genus Apis only $A$. dorsata Fabr., the giant honey bee, appears free from attack by hornets (Seeley et al. 1982). De Jong (1978) reviewed the records of Vespa predation on $A$. mellifera and $A$. cerana Fabr. Matsurra and Sakagami (1973) provided a detailed description on $V$. mandarinia Smith attack behavior on A. mellifera in Japan.

We observed the predation and ultimate destruction of a small $A$. mellifera colony by $V$. tropica (L.) on the Kamphaeng Saen campus of Kasetsart University, Nakorn Pathom, Thailand, during a four day period in December 1981. The honey bee colony consisted of four standard frames with a comb area of ca. $7,000 \mathrm{~cm}^{2}$ in a hive body with a volume of 211 . The colony entrance was restricted to an area of ca. $3.5 \mathrm{~cm}^{2}$. The colony possessed one comb approximately one-half full of capped honey, two empty combs, one comb with an active brood nest and an estimated $0.5 \mathrm{~kg}$ of worker bees which occupied two combs. The brood nest was infested with the parasitic brood mite Tropilaelaps clareae Delfinado and Baker.

Uninterrupted observations of hornet behavior at the colony were conducted on December 21 and 23 for a total of $19 \mathrm{~h}$ and $50 \mathrm{~min}$. To facilitate the observations eight individual hornets were tagged on their thoraces with color and number coded discs. Observations were begun at $0730 \mathrm{~h}$ on the 21 st and 0715 on the $23 \mathrm{rd}$ and continued until after $1700 \mathrm{~h}$ on both days. The ambient temperature was $16^{\circ} \mathrm{C}$ at the start of observations on both days and reached a maximum of $25^{\circ} \mathrm{C}$ by mid-afternoon.

We estimate that 25 to 35 hornets were involved in this predatory episode. One of us (P.A.) first noted the presence of a few hornets at

\footnotetext{
'Department of Entomology, Oregon State University, Corvallis, Oregon 97331 2Department of Entomology, Kasetsart University, Kamphaeng Saen, Thailand Manuscript received by the editor September 9, 1982.
} 
the colony some ten to 12 days prior to the 21 st. This would correspond to what Matsuura and Sakagami (1973) describe as the hunting phase for $V$. mandarinia. By the 21 st the attack had escalated to the slaughter phase where nearly two score of hornets were concentrating upon the now weakened honey bee colony.

The hornet attack was a campaign of slow attrition for the honey bees. Usually two to five hornets would position themselves at the colony entrance. They would engage any honey bee entering or exiting the hive. The large hornets had no difficulty in seizing the bees and would maul them with their strong mandibles. The hornets would normally drop the disabled bees to the ground and only rarely was a moribund bee observed to be eaten by a hornet. The guard hornets would frequently position themselves in the entrance passageway with only their abdomens visible to the observer. These hornets would engage individual guard bees just inside the entrance and after seizing a bee, quickly drag it out and drop it off the landing board to the ground. A separate cadre of hornets would enter the colony and position themselves on the comb containing capped honey. This peripheral comb was without bees which were concentrated on the brood comb. Honey scavenging hornets would spend long periods of time within the colony uncapping honey storage cells and engorging themselves on the contents. On the 21 st the average time spent by a hornet inside the colony was $22.9 \pm 17.7 \mathrm{~min}$ $(n=64)$. Upon emerging from the hive the scavenger hornets were frequently antennated by the guard hornets, and an exchange of alimentary fluid would usually result.

Continuous observation at the colony was not conducted on December 22. However, a one $\mathrm{m}^{2}$ piece of plywood was placed directly in front of the hive to facilitate an estimate of adult honey bee mortality. Between 0930 and 1415 h 119 dead honey bees had been deposited on the plywood by guard hornets. At $1420 \mathrm{~h}$ the colony absconded and within ten minutes had clustered on a small shrub ca. $15 \mathrm{~m}$ north of the hive. For the remainder of the afternoon hornets were observed for the first time exiting the hive with larvae and pupae scavenged from the brood nest. At $1930 \mathrm{~h}$ on the $22 \mathrm{nd}$ we reintroduced the swarm cluster and queen back into the hive.

Observations on the $23 \mathrm{rd}$ began at $0715 \mathrm{~h}$. At $0834 \mathrm{~h}$ the colony 
once again absconded. Several guard hornets were at the hive entrance during the exodus of the bees. The hornets physically engaged scores of worker bees, mauling and tossing them to the ground. The queen was seen emerging from the hive at $0838 \mathrm{~h}$. She was immediately approached by a hornet which attacked her. She was able to disengage herself from the hornet at the cost of the tarsi from her left front leg. She flew to the branch of a small tree ca. three $\mathrm{m}$ from the hive and the worker bees began clustering around her.

With the abandonment of the hive the hornets began to concentrate on the undefended brood nest. From 0845 to $1705 \mathrm{~h}$ hornets were observed on 109 occasions to exit the hive with brood as prey. The time individual hornets spent inside the hive was significantly shorter, ave. $13.1 \pm 11.3 \mathrm{~min}(\mathrm{n}=127)$, than on the 21 st when bees were present to mount a defense of the colony. The number of foraging events by individual hornets showed a corresponding increase with the departure of the bees. On the $21 \mathrm{st}$, with the bees present, eight marked hornets were observed to conduct 94 complete forays upon the colony for an average of $10.6 \pm 6.4$ trips per hornet. On the 23rd eight marked hornets completed 171 trips for an average of $21.4 \pm 6.0$ trips per hornet.

An examination of the hive interior on December 24 revealed that the hornets had completely removed all larvae and pupae from the brood comb. The honey storage comb contained less than an estimated $500 \mathrm{~g}$ of honey. Hornet traffic at the hive was considerably reduced from the previous three days. Occasional observations of the hive throughout the day revealed at most, six hornets still engorging on the remaining honey.

Apis mellifera is an introduced species to Southeast Asia (Akratanakul 1976). The colony we observed came from stock originally imported from California in 1979. Absconding by $A$. mellifera in temperate climates is an unusual phenomenon. However, absconding by other species of tropical Apis is a common defensive strategy (Seeley et al. 1982). It is interesting to note that $A$. mellifera from temperate origins still retains absconding as a defense mechanism in the face of severe predation. 


\section{REFERENCES CITED}

Akratanakul, $P$.

1976. Honey bees in Thailand. Amer. Bee. J. 116: 120-121, 124, 126.

DE JoNG, D.

1978. Insects: Hymenoptera (ants, wasps and bees). pp. 138-157. In: Honey Bee Pests, Predators and Diseases. R.A. Morse, Editor, Cornell Univ. Press, Ithaca, NY.

MatsuUra, M. and S. F. Sakagami

1973. A bionomic sketch of the giant hornet Vespa mandarinia, a serious pest for Japanese apiculture. J. Fac. Sci. Hokkaido Univ. (Ser. Zool.) 19: 125-162.

Seeley, T. D., Seeley, R. H. and P. Akratanakul

1982. Colony defense strategies of the honeybees in Thailand. Ecol. Mono. 52: 43-63. 

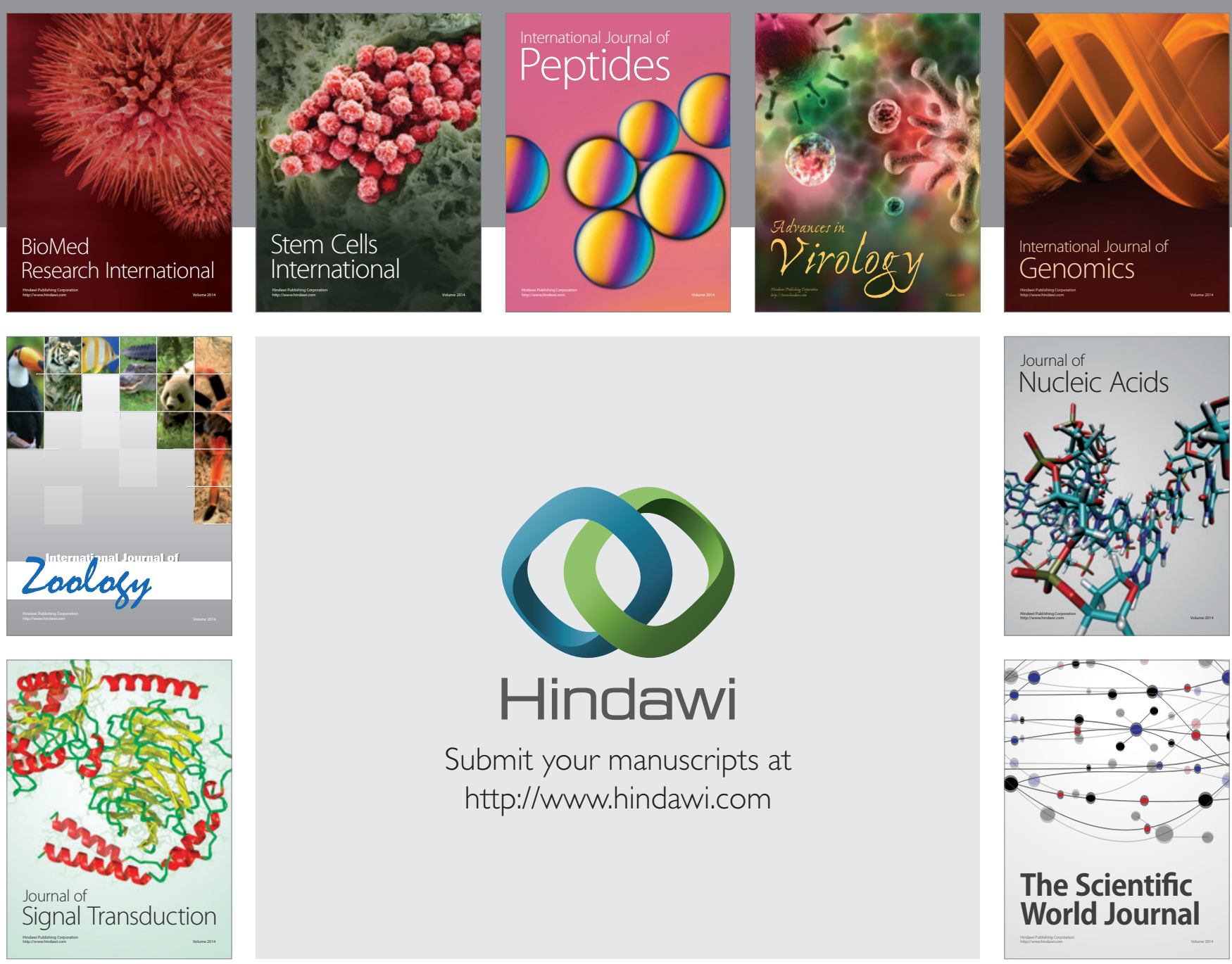

Submit your manuscripts at

http://www.hindawi.com
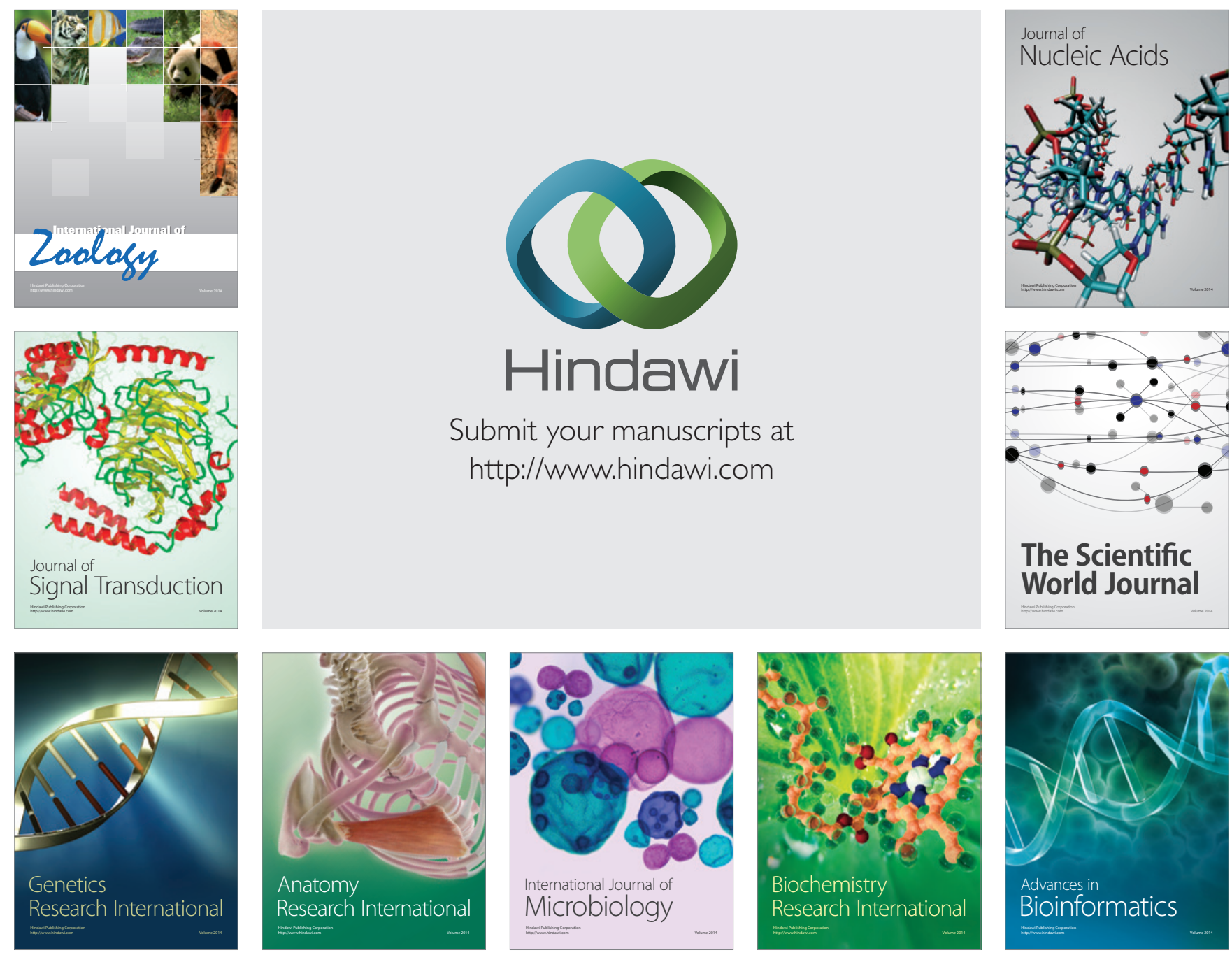

The Scientific World Journal
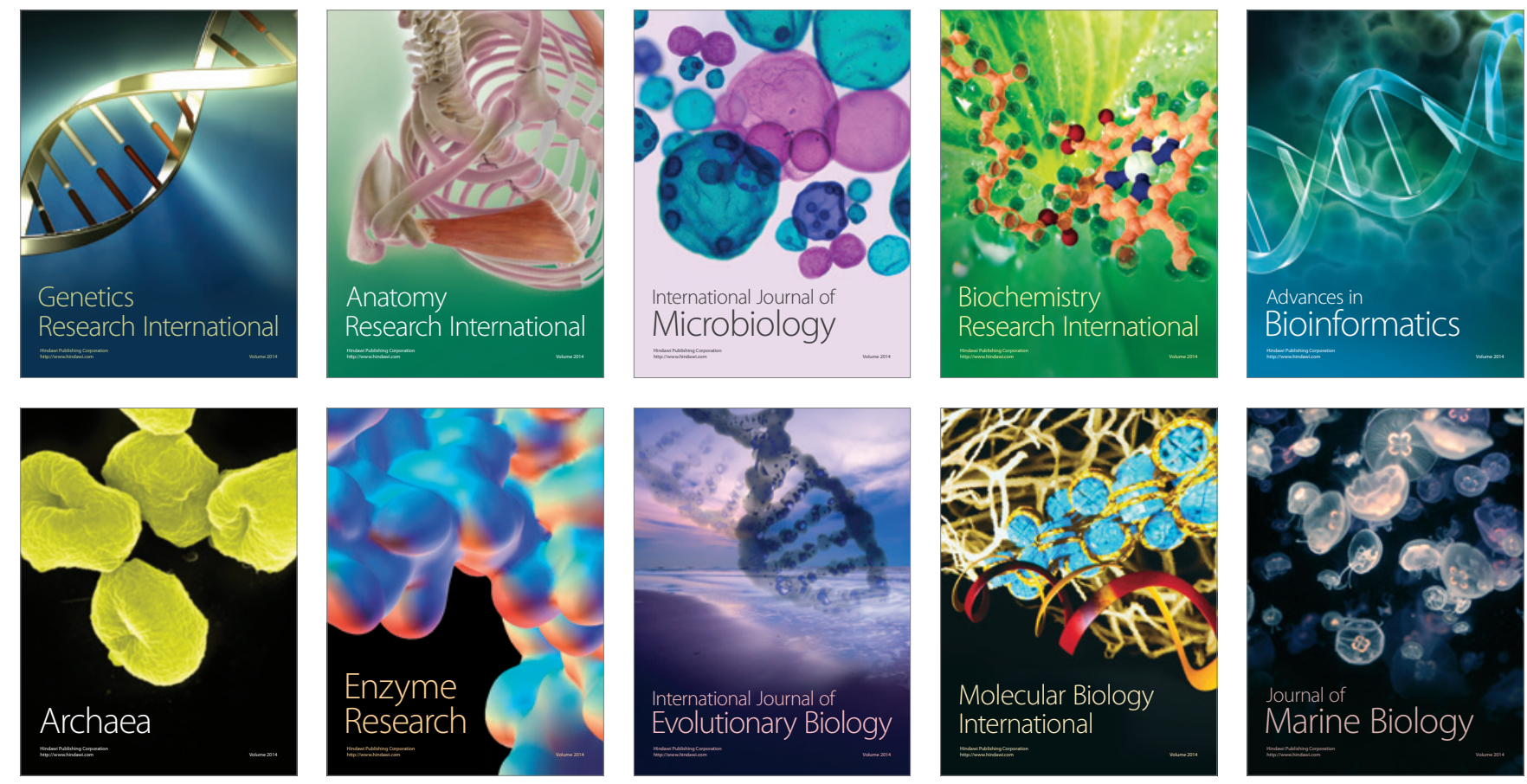